\title{
Effects of microbial phytase supplementation of a barley-soybean meal diet on the performance and bone mineralization of growing-finishing pigs
}

\begin{abstract}
EiJa Helander
HELANDER, E. 1994. Effects of microbial phytase supplementation of a barleysoybean meal diet on the performance and bone mineralization of growingfinishing pigs. Agricultural Science in Finland 3: 439-448. (Department of Animal Science, P.O. Box 28, FIN-00014 University of Helsinki, Finland.)

The study evaluated the effect of a phytase supplement, produced by Aspergillus niger, on the performance of 72 growing-finishing pigs (28-101 kg). Chemical and physical parameters of the tibia and fibula bones were measured. The control diet (diet 1) was formulated to be adequate for pigs with respect to all nutrients, and diets 2 and 3 with respect to all other nutrients except total phosphorus (P). The $\mathrm{P}$ source of the control diet was dicalciumphosphate (dihydrate), while no inorganic $\mathrm{P}$ was added to diets 2 and 3 . Diet 3 was supplemented with phytase, $720 \mathrm{U} / \mathrm{kg}$ feed. The average daily gain (ADG) and the feed conversion ratio (FCR) of the control pigs were significantly better than those of the groups without inorganic $\mathrm{P}$. Phytase improved the ADG ( $\mathrm{p}<0.01)$ and the FCR during the first 45 days $(28$ $60 \mathrm{~kg}$ ). The pigs on diet 2 were able to grow as well as the other pigs when they became heavier (between $60-100 \mathrm{~kg}$ ), so that at the end of the trial there was no significant difference between diets 2 and 3 for these parameters. No signs of leg weakness were observed in the growing pigs on any of the diets. The density $(p<0.01)$ and the breaking strength $(p<0.01)$ of the tibia bone were reduced $(\mathrm{p}<0.01)$ on low-P diets compared to control diet. Phytase supplementation improved the density of the tibia bone $(\mathrm{p}<0.001)$ compared to diet 2 and tended to improve the breaking strength, but the difference was not significant. No differences were found in the ash or P contents of the fibula bones. Phosphorus emissions were markedly reduced on diets 2 and 3 . On the basis of the results it is not possible to recommend to replace inorganic $\mathrm{P}$ totally by phytase in growing-finishing pigs on barley-SBM diets.
\end{abstract}

Key words: phosphorus, availability

\section{Introduction}

Approximately one percent of a mature pig's body weight consists of phosphorus (PEO 1991). Fourfifths of it is concentrated in the skeleton while the rest can be found in soft tissues in different organic compounds participating in nearly all biochemical reactions occurring in the pig's body (Cromwell 1989). In plants, phosphorus (P) is to a great extent in the form of organic calcium and magnesium salts of myo-inositol hexaphosphate (phytic acid), the bioavailability of which varies depending on the species of plant and their phytic acid and intrinsic phytase content (JONGBLOED 1987). In diet formulation, the $P$ availability is normally calculated to be only 0.30 in vegetable feed ingredients. To ensure that the phosphorus requirements of animals are met, feed mix- 
tures are usually supplemented with inorganic phosphorus. The low utilization of dietary $\mathrm{P}$ results in a high amount of it excreted in manure. This can lead to an accumulation of $\mathrm{P}$ in the soil and a consequent disruption of the normal life cycle of various organisms in nature. Possibilities to decrease the use of $\mathrm{P}$ in pig feeds have therefore been studied for years.

One of the key factors in decreasing the total phosphorus content of pig feeds is to make the organic phytic phosphorus of plants bioavailable for animals. Trials have included soaking the feed before feeding (JONGBLOED 1987, KEMME and JoNGBlOED 1993, NÄSI and HelandER 1994) or adding microbiologically produced phytase to the feed. Most of the studies on the effects of microbial phytases have so far been conducted on young pigs on maize-soybean meal based diets (SIMONS et al. 1990, Jongbloed et al. 1991a, BeERS and Jongbloed 1992a,b, Lei et al. 1992, PALlauf et al. 1992, Eeckhout and De PAePe 1992, Hoppe et al. 1993, Kemme and JongBloed 1993). However, $0.60-0.70$ of the phosphorus excretion of pigs originates from the growing-finishing pigs. Attempts to reduce the excretion of $\mathrm{P}$ should therefore be especially directed at growing-finishing pigs (JONGBLOED and LeNIS 1993). In Finland and in many other areas the main cereal in pig diets is barley, the phytate and phytase contents of which differ from maize (CROMWELL 1992).

The aim of the present experiment was to evaluate whether a Aspergillus niger phytase preparation could improve the utilization of the intrinsic phosphorus of commercial barley-soybean meal-based pelleted feed mixtures and thus replace the added inorganic dietary P. The performance of the growing-finishing pigs as well as different bone parameters were used as response criteria of the enzyme effect. A digestibility and balance experiment was carried out simultaneously with the same feeds (NÄSI and HELANDER 1994).

\section{Material and methods}

A feeding trial was conducted with 72 commercial crossbred pigs from $28 \mathrm{~kg}$ live weight to an average live weight of $101 \mathrm{~kg}$ at slaughter. The pigs were allocated into three blocks on the basis of weight. Eight pigs from each block were assigned at random to one of three experimental diets. Four pigs were placed into each pen and each diet was tested on three pens of barrows and three pens of gilts. The animals were group-housed in concrete-floor pens and group-fed. No bedding was used.

The pigs were fed pelleted $\left(65^{\circ} \mathrm{C}, 4 \mathrm{~mm}\right.$ diameter) barley-soybean meal based complete mixtures. The same feed mixtures were used in a separate digestibility and balance experiment (NÄSI and HElander 1994). The control diet (diet 1) was adequate for pigs with respect to all nutrients (SALO et al. 1990) and the experimental diets (diet 2 and diet 3) with respect to all other nutrients except total $\mathrm{P}$. The inorganic $\mathrm{P}$ source on the control diet was dicalciumphosphate (dihydrate). The experimental diets 2 and 3 were not supplemented with inorganic P. The control diet was calculated to contain $3.1 \mathrm{~g}$ and the experimental diets $1.2 \mathrm{~g}$ digestible $\mathrm{P}$ per $\mathrm{kg}$. The total $\mathrm{P}$ values of the feed raw materials needed for calculations were based on the results of several analyses obtained from the feed factory. The values were $3.1 \mathrm{~g} / \mathrm{kg}$ for barley, $6.6 \mathrm{~g} / \mathrm{kg}$ for soybean meal (440 $\mathrm{g}$ crude protein and $40 \mathrm{~g}$ crude fat per $\mathrm{kg}$ soybean meal, SBM) and $174 \mathrm{~g} / \mathrm{kg}$ for dicalciumphosphate. Diet 3 was supplemented with a phytase prepared using Aspergillus niger (Natuphos $^{R}$ 5000, Gist-brocades, The Netherlands), at a level of $0.24 \mathrm{~g} / \mathrm{kg}(1200 \mathrm{U} / \mathrm{kg})$. The calcium content was calculated to be $8.0 \mathrm{~g} / \mathrm{kg}$ on all diets and the vitamin D content $800 \mathrm{IU} / \mathrm{kg}$ feed. The composition of the diets is shown in Table 1 . The pigs were restrictedly group-fed according to body weight using a scale from 1.5 to 2.85 feed units/pig/day ( $F U=0.7$ starch equivalents). The daily feed allowance was changed once a week. Feeds were offered twice a day, and water was available ad libitum. The pigs were weighed on days $0,21,45,63,84$ from the beginning of the trial and again at the end of the trial. The feed consumption was registered penwise during the experiment.

At slaughter, the carcass weight was recorded 
Table 1. Dietary ingredients $(\%)$, analyzed protein and calculated $\mathrm{P}, \mathrm{Ca}$ and energy contents of the experimental feeds.

\begin{tabular}{|c|c|c|c|}
\hline & Diet $1^{1}$ & Diet 2 & Diet 3 \\
\hline Barley & 76.0 & 76.8 & 76.8 \\
\hline Soybean meal & 19.5 & 19.3 & 19.3 \\
\hline \multicolumn{4}{|l|}{ Dicalciumphosphate } \\
\hline (dihydrate) & 1.6 & & \\
\hline Limestone & 0.7 & 1.7 & 1.7 \\
\hline Molasses & 1.0 & 1.0 & 1.0 \\
\hline Serla Bondex (a pellet bi & 0.5 & 0.5 & 0.5 \\
\hline $\mathrm{NaCl}$ & 0.4 & 0.4 & 0.4 \\
\hline Trace mineral $\mathrm{mix}^{2}$ & 0.2 & 0.2 & 0.2 \\
\hline Vitamin $\mathrm{mix}^{3}$ & 0.1 & 0.1 & 0.1 \\
\hline Phytase $^{4}$ & - & - & 0.024 \\
\hline Crude protein, g/kg DM & 1.) 189 & 187 & 190 \\
\hline Phosphorus, g/kg (calc.) & 6.5 & 3.7 & 3.7 \\
\hline Calcium, g/kg (calc.) & 8.0 & 8.0 & 8.0 \\
\hline Feed unit $(\mathrm{FU} / \mathrm{kg})^{5}$ & 1.0 & 1.0 & 1.0 \\
\hline $\mathrm{ME}, \mathrm{MJ} / \mathrm{kg}$ & 12.5 & 12.5 & 12.5 \\
\hline
\end{tabular}

1. Diet $1=$ inorganic $P$ supplementation, Diet $2=$ no inorganic P supplementation, Diet $3=$ like diet $2+$ phytase addition.

2. Supplied per kg diet, $20 \mathrm{mg} \mathrm{Fe}, 21 \mathrm{mg} \mathrm{Mn}, 21 \mathrm{mg} \mathrm{Cu}$, $73 \mathrm{mg} \mathrm{Zn,0.2} \mathrm{mg} \mathrm{I,} 0.1 \mathrm{mg} \mathrm{Se}$.

3. Supplied per kg diet, $5000 \mathrm{IU}$ vitamin $\mathrm{A}, 800 \mathrm{IU}$ vita$\min \mathrm{D}, 60 \mathrm{mg}$ vitamin E, $2 \mathrm{mg}$ vitamin $\mathrm{K}, 2 \mathrm{mg}$ thiamin, $3 \mathrm{mg}$ riboflavin, $20 \mu \mathrm{g}$ vitamin B12,50 $\mu \mathrm{g}$ biotin, $10 \mathrm{mg}$ pantothenic acid, $20 \mathrm{mg}$ niacin.

4. Natuphos ${ }^{R} 5000$ phytase (Gist-brocades, The Netherlands).

5. $\mathrm{FU}=0.7 \mathrm{~kg}$ starch equivalent.

and the quality grade determined with an automatic Hennessy $\mathrm{GP}_{2}$ device. The lean content was estimated from measurements of back fat, eye muscle depth and carcass weight (ENGLISH et al. 1988). A quality grading of 9 points was equivalent to a meat percentage over 61,8 to $59-60,7$ to $52-58$ and 6 below 51 . The tibia and fibula bones from the left hind leg were removed from eight pigs per treatment. The bone samples were frozen $\left(-18^{\circ} \mathrm{C}\right)$ to await chemical and physical analyses. Dry matter content, the concentration of ash, $\mathrm{Ca}, \mathrm{P}$ and density of the diaphyses of the fibula bones, as well as density and breaking strength of the tibia bones, were determined. The densities of the bones were measured by weigh- ing the bones from which the soft tissues had been removed, placing the whole bones into water and recording the quantity of water replaced by the bones, after which the weight-to-volume ratio was calculated. The breaking strength was determined with an Instron Testing Instrument (Model 1112) by recording the amount of force applied at a constant speed of $5 \mathrm{~cm} / \mathrm{min}$ required to break a $3.7 \mathrm{~cm}$ piece of the mid-diaphysis placed in a horizontal position on a support. Two samples from each bone were measured, and the mean value was used for the statistical analysis. For dry matter determination, small pieces of the fibula bones' diaphyses from which the visible fat had been removed, were dried in a $105^{\circ} \mathrm{C}$ oven overnight. The ash percentage was determined by placing the dried bones in a $525^{\circ} \mathrm{C}$ muffle furnace for 16 hours.

The chemical analyses of the feeds were conducted by standard methods (AOAC 1984). In the determination of phytic acid, ICP-AES method was used to determine P (PLAAMI and KUMPULAINEN 1991). In this method the P content of the sample is indirectly measured by atomic emission spectrophotometry after burning the sample by inductively coupled plasma. $\mathrm{P}$ from the feeds and bones was analyzed after dry ashing colorimetrically by the vanadomolybdate procedure of TAYSSKY and SHORR (1953). The calcium contents of the feeds and bones were measured with a Perkin-Elmer 5100 PC atomic-absorption spectrophotometer. The phytase activity of the main raw materials, of diets and of Natuphos was measured spectrophotometrically as free phosphate from phytate after incubating the sample in a 0.1 $\mathrm{M}$ sodium acetate buffer, $\mathrm{pH} 5.0$, at $35^{\circ} \mathrm{C}$ for 30 minutes (Puhakka, Cultor Research Center). A phytase unit is defined as the amount of enzyme that liberates $1 \mu \mathrm{mol}$ of inorganic P from sodium-phytate in one minute.

The data were subjected to an analysis of variance using the GLM procedure of SAS (1985). A split-plot design was used for the statistical analysis of periodical average daily gain (ADG) and feed conversion ratio (FCR). In the performance data the mean of each pen was used as an observation for the statistical analysis. The following 
model was used in analyzing the performance data (SNEDECOR and COCHRAN 1989):

$$
\begin{aligned}
\mathrm{Y}_{\mathrm{ijk}} & =\mu+\mathrm{B}_{\mathrm{i}}+\mathrm{T}_{\mathrm{j}}+\mathrm{S}_{\mathrm{k}}+\left(\mathrm{T}^{*} \mathrm{~S}\right)_{\mathrm{jk}}+\mathrm{e}_{\mathrm{ijk}}, \text { where } \\
\mu & =\text { overall mean } \\
\mathrm{B}_{\mathrm{i}} & =\text { effect of block } i \\
\mathrm{~T}_{\mathrm{j}} & =\text { effect of treatment } j \\
\mathrm{~S}_{\mathrm{k}} & =\text { effect of sex } k \\
\left(\mathrm{~T}^{*} \mathrm{~S}\right)_{\mathrm{jk}} & =\text { interaction between sex and treatment } \\
\mathrm{e}_{\mathrm{ijk}} & =\text { residual term }
\end{aligned}
$$

The mean initial weight of a pen was used as a covariate in analyzing days in the experiment, weight gain, ADG, feed consumption and FCR. In analyzing the bone data the final live weight was used as a covariate. Differences were compared using orthogonal contrasts as follows: $\mathrm{C} 1$ = inorganic $\mathrm{P}$ supplement vs. without $\mathrm{P}$ supplement (Diet 1 vs. Diets 2 and 3), C2 = no phytase supplement vs. phytase supplement (Diet 2 vs. Diet 3).

\section{Results and discussion}

\section{Analyses}

The detailed chemical composition of the diets has been published earlier by NÄSI and HELANDER (1994). The total P content was $0.7 \mathrm{~g} / \mathrm{kg}$ higher and the $\mathrm{Ca}$ content $0.3 \mathrm{~g} / \mathrm{kg}$ lower in diet 1 than calculated $(6.5 \mathrm{~g} / \mathrm{kg} \mathrm{P}$ and $8.0 \mathrm{~g} / \mathrm{kg}$ $\mathrm{Ca}$. In addition, the $\mathrm{P}$ content in diets 2 and 3 was $0.5 \mathrm{~g} / \mathrm{kg}$ higher and Ca content $0.7 \mathrm{~g} / \mathrm{kg}$ lower than calculated. Thus, the $\mathrm{Ca}$ to $\mathrm{P}$ ratios of the diets were lower than expected (Table 2). The analyzed total $\mathrm{P}$ content of the barley batch used in this trial was $3.6 \mathrm{~g} / \mathrm{kg}$ and of soybean meal $4.8 \mathrm{~g} / \mathrm{kg}$ on average. The $\mathrm{P}$ content of barley was on the same level as reported by OKSBJERG (1988) and Veevoedertabel (1991) but was lower than the values measured by PoINTILLART (1988) and Jongbloed and Kemme (1990). The P content of SBM was lower than the values reported by PoINTILlart (1988), Jongbloed and Kemme (1990), Veevoedertabel (1991) and KETAREN et al. (1993). In Finnish feedtables (SALO et al. 1990) the values of $\mathrm{P}$ are 3.5 and $7.3 \mathrm{~g} / \mathrm{kg} \mathrm{DM}$ for barley and SBM, respectively.

Using the measured digestibility coefficients $0.55,0.45$ and 0.65 for P (NÄSI and HELANDER 1994) in diets 1,2 and 3, respectively, and the determined total $\mathrm{P}$ contents, it can be calculated that diet 1 contained $3.9 \mathrm{~g}$, diet $21.8 \mathrm{~g}$, and diet $32.6 \mathrm{~g}$ digestible $\mathrm{P} / \mathrm{kg}$.

\begin{tabular}{|c|c|c|c|c|c|}
\hline $\begin{array}{l}\text { Treatment } \\
\text { Composition, g/kg }\end{array}$ & Diet $1^{1}$ & Diet 2 & Diet 3 & Barley & SBM \\
\hline Phosphorus & 7.2 & 4.1 & 4.1 & 3.6 & 4.8 \\
\hline Phytic acid & 9.3 & 9.3 & 9.9 & 8.1 & 10.1 \\
\hline $\mathrm{P}$ from phytic $\mathrm{P}\left({ }^{*} 0.282\right)$ & 2.6 & 2.6 & 2.8 & 2.3 & 2.8 \\
\hline Phytic P \% of total P & 36.1 & 63.4 & 68.3 & 63.9 & 58.3 \\
\hline Phytase, U/kg & $<1000$ & 400 & 1600 & 300 & n.d. ${ }^{2}$ \\
\hline Dig. P (measured) & 3.9 & 1.8 & 2.6 & & \\
\hline Calcium & 7.7 & 7.3 & 7.3 & & \\
\hline $\mathrm{Ca}: \mathrm{P}$ ratio & 1.06 & 1.78 & 1.78 & & \\
\hline Ca:dig. $\mathrm{P}$ ratio & 1.95 & 4.10 & 2.83 & & \\
\hline
\end{tabular}

The interpretation of the enzyme activity measurements is somewhat questionable, because the assays were performed according to methods which have not been validated (Puhakka, Cultor Research Centre). The method is not sensitive

Table 2. Analyzed $\mathrm{P}$ and Ca contents of the experimental diets, barley and soybean meal (SBM).

1. Diet $1=$ inorganic $P$ supplementation, Diet $2=$ no inorganic $P$ supplementation, Diet $3=$ like diet 2 + phytase addition.

2. n.d. = not detected. 
Table 3. Performance, feed consumption and carcass quality of pigs.

\begin{tabular}{|c|c|c|c|c|c|c|c|c|c|c|c|}
\hline Treatment & Diet $1^{1}$ & Diet 2 & Diet 3 & SEM $^{2}$ & Females & Castrates & SEM & $\mathrm{Cl}^{3}$ & $\mathrm{C} 2$ & Sex & $\begin{array}{r}\text { Sex* } \\
\text { diet }\end{array}$ \\
\hline No of observ. ${ }^{4}$ & 6 & 6 & 6 & 9 & 9 & & & & & & \\
\hline Initial weight,kg & 27.7 & 28.2 & 27.6 & 0.99 & 27.9 & 27.8 & 0.81 & NS & NS & NS & NS \\
\hline Final weight,kg & 102.0 & 101.5 & 100.2 & 0.89 & 100.6 & 101.8 & 0.73 & NS & NS & NS & NS \\
\hline Days in experiment & 88.6 & 92.4 & 90.0 & 1.04 & 91.8 & 88.8 & 0.85 & o & NS & $*$ & NS \\
\hline Daily gain, g & 843 & 797 & 810 & 11.0 & 796 & 837 & 8.9 & $*$ & NS & ** & NS \\
\hline Feed cons. FU/pig & 203.9 & 212.9 & 209.6 & 2.27 & 208.4 & 209.2 & 1.85 & * & NS & NS & NS \\
\hline FU/pig/day ${ }^{5}$ & 2.30 & 2.31 & 2.33 & 0.029 & 2.27 & 2.36 & 0.024 & NS & NS & $*$ & NS \\
\hline FCR, FU/kg gain & 2.75 & 2.90 & 2.89 & 0.034 & 2.86 & 2.83 & 0.028 & $* *$ & NS & NS & NS \\
\hline Carcass weight, kg & 76.7 & 75.2 & 75.9 & 0.67 & 76.3 & 75.6 & 0.54 & NS & NS & NS & NS \\
\hline $\begin{array}{l}\text { Carcass quality } \\
\text { grade points }\end{array}$ & 8.5 & 8.5 & 8.5 & 0.07 & 8.75 & 8.22 & 0.06 & NS & NS & *** & ** \\
\hline
\end{tabular}

1. Diet $1=$ inorganic P supplementation, Diet $2=$ no inorganic P supplementation, Diet $3=$ like diet $2+$ phytase addition.

2. $\mathrm{SEM}=$ standard error of mean.

3. $\mathrm{Cl}=$ Diet 1 vs. Diets 2 and 3.

$\mathrm{C} 2=$ Diet 2 vs. Diet 3 .

NS non-significant, ${ }^{*}(\mathrm{p}<0.05),{ }^{* *}(\mathrm{p}<0.01),{ }^{* * *}(\mathrm{p}<0.001), \mathrm{o}(\mathrm{p}<0.1)$.

4. Four pigs per observation.

5. $F U=$ feed unit.

enough. Given this, the phytase activity of the barley used was found to be $300 \mathrm{U} / \mathrm{kg}$, which is lower than that measured from Dutch summer barley (630 U/kg) by JONGBLOED et al. (1991b). The discrepancy in enzyme analytics can be clearly seen in the phytase activities measured from the diets: diet 1 contained $<1000 \mathrm{U} / \mathrm{kg}$, diet 2 $400 \mathrm{U} / \mathrm{kg}$, while barley contained the aforementioned $300 \mathrm{U} / \mathrm{kg}$ and soybean meal none. A comparison of the measured phytase activities of the raw materials and diet 2 suggests that pelleting did not decrease the intrinsic phytase activity of the feeds. The analyzed phytase activity of the enzyme product was $3000 \mathrm{U} / \mathrm{g}$ instead of the $5000 \mathrm{U} / \mathrm{g}$ quoted by the manufacturer, but there were differences in the determination methods between Gist-brocades and Cultor Research Centre. Even though the measured supplementation level was $720 \mathrm{U} / \mathrm{kg}$ feed instead of targeted 1200 $\mathrm{U} / \mathrm{kg}$, the total phytase activity in diet 3 was measured to be $1600 \mathrm{U} / \mathrm{kg}$. Despite the inaccuracy in the enzyme activity analytics it can be concluded that the phytase addition to diet 3 could be detected.

\section{Performance}

The ADG from $28 \mathrm{~kg}$ to slaughter was 843,797 and $810 \mathrm{~g}$ on diets 1,2 and 3 , respectively (Table $3)$. The ADG of the control group was significantly $(\mathrm{p}<0.05)$ higher than that of the groups with no inorganic P. Phytase did not have any significant effect on ADG. Косн et al. (1984) and Den HARTOG et al. (1988) reported a reduced growth rate when diets deficient in utilizable $\mathrm{P}$ were fed. A tendency towards lower growth rates was also observed by JongBLOED (1987) with diets containing $1.5 \mathrm{~g}$ digestible $\mathrm{P} / \mathrm{kg}$, which was due to a lower feed intake of pigs from $30 \mathrm{~kg}$ live weight onwards. In the present trial, there was no significant difference in average daily feed consumption between the treatments. JONGBLOED et al. (1991a) recommended $2.3 \mathrm{~g}$ digestible $\mathrm{P} / \mathrm{kg}$ in diets for $30 \mathrm{~kg}$ growing pigs, $2.0 \mathrm{~g}$ for $50 \mathrm{~kg}$ pigs and $1.5 \mathrm{~g}$ for $100 \mathrm{~kg}$ pigs. These calculations were based on an ADG of $780 \mathrm{~g}$ and a FCR of $3.0 \mathrm{~kg} / \mathrm{kg}$ gain. Assuming that the energy level of the feed was about 9.0 $\mathrm{MJ} \mathrm{NE}_{\mathrm{f}}(=1.0 \mathrm{FU})$ and that the Dutch allowance recommendations are 
Table 4. Periodical $\mathrm{ADG}^{\prime}$ and $\mathrm{FCR}^{2}$.

\begin{tabular}{|c|c|c|c|c|c|c|c|c|c|c|}
\hline \multirow[b]{2}{*}{ Period, days } & \multicolumn{5}{|c|}{ ADG } & \multicolumn{5}{|c|}{ FCR } \\
\hline & Diet $1^{3}$ & Diet 2 & Diet 3 & $\mathrm{C} 1^{4}$ & $\mathrm{C} 2$ & Diet 1 & Diet 2 & Diet 3 & $\mathrm{C} 1$ & $\mathrm{C} 2$ \\
\hline $0-21$ & 696 & 595 & 681 & $*$ & ** & 2.39 & 2.74 & 2.50 & $* *$ & ** \\
\hline $22-45$ & 973 & 848 & 925 & *** & $* *$ & 2.34 & 2.52 & 2.42 & $*$ & o \\
\hline $46-63$ & 845 & 830 & 809 & NS & NS & 3.07 & 3.11 & 3.30 & $*$ & $*$ \\
\hline $64-84^{5}$ & 772 & 802 & 766 & NS & NS & 3.34 & 3.26 & 3.44 & NS & o \\
\hline
\end{tabular}

1. Average daily gain $(\mathrm{g})$.

2. Feed conversion ratio (FU/kg gain).

3. Diet $1=$ inorganic P supplementation, Diet $2=$ no inorganic $P$ supplementation, Diet $3=$ like diet $2+$ phytase addition.

4. $\mathrm{C} 1=$ Diet 1 vs. Diets 2 and 3 .

$\mathrm{C} 2=$ Diet 2 vs. Diet 3 .

NS non-significant, ${ }^{*}(\mathrm{p}<0.05),{ }^{* *}(\mathrm{p}<0.01),{ }^{* * *}(\mathrm{p}<0.001), \mathrm{o}(\mathrm{p}<0.1)$.

5 . Last period (after 85 days) not tested, because the groups were no longer complete.

valid in Finnish circumstances, and further taking into account the restricted feeding regime in our trial, the need of digestible $\mathrm{P}$ requirement $/ \mathrm{kg}$ feed was slightly higher in our case. However, diet 3 should have contained enough digestible $\mathrm{P}$ $(2.6 \mathrm{~g} / \mathrm{kg})$ for the whole growing period. De WILDE and JouRQUIN (1992) on the other hand observed that a ration with a digestible $\mathrm{P}$ content of $3.4 \mathrm{~g} / \mathrm{kg}$ was more favourable for performance than one of $2.6 \mathrm{~g} / \mathrm{kg}$ during the early growing phase $(18-36 \mathrm{~kg})$ of pigs. The initial weight of the pigs in the present study was higher, about 28 $\mathrm{kg}$, and the periodical growth results (Table 4) prove that there was not shortage of digestible $\mathrm{P}$ at that stage.

The ranges for optimal $\mathrm{Ca}$ to total $\mathrm{P}$ ratios of diets for growing pigs are rather wide. The ratio should be between 1.0 and 2.0 , the optimum being between $1.2-1.4$ to 1 for the best utilization of $\mathrm{P}$ and performance of pigs (JONGBLOED 1987). Widening the $\mathrm{Ca}$ to $\mathrm{P}$ ratio tends to reduce performance, especially when the dietary level of $\mathrm{P}$ is marginal or deficient (REINHART and MAHAN 1986). In our diets the ratios were 1.06 to $1,1.78$ to 1 and 1.78 to 1 (Table 2). Calcium to digestible $\mathrm{P}$ ratios of diets 1,2 and 3 were approximately 2.0 to $1,4.0$ to 1 and 2.8 to 1 . JonGBLOED (1987) suggested that this ratio should be between 2.9 and 3.5 to 1 for growing pigs. Digest- ible $\mathrm{Ca}$ to digestible $\mathrm{P}$ ratios were $0.80,1.90$ and 1.40 for diets 1, 2 and 3, respectively (NÄSI and Helander 1994). The average Ca to $\mathrm{P}$ ratio of the pig's whole body is about 1.6. This suggests that the amount of digestible $\mathrm{Ca}$ should be close to 1.6 times that of digestible $\mathrm{P}$ in pig diets (JONGBLOED 1987). Thus, the reasons for why the differences in ADG were not very remarkable between the treatments may be the higher than presumed digestible $\mathrm{P}$ content of all the diets and the suboptimal (total and digestible) Ca to $\mathrm{P}$ ratios. However, the ADG of the control group pigs was so much better that they tended $(p=0.07)$ to reach slaughter weight faster than the other animals.

Total feed consumption was lowest $(\mathrm{p}<0.05)$ and feed conversion most efficient on diet 1 $(\mathrm{p}<0.01)$. Pigs on diets 2 and 3 needed $150 \mathrm{~g}$ and $140 \mathrm{~g}$, respectively, more feed per $\mathrm{kg}$ live weight gain than the control pigs. Other research has also indicated that a low dietary P level may adversely affect feed conversion (CROMWELL et al. 1972, KoCH and MaHAN 1985, ReINHART and Mahan 1986). Phytase supplementation did not improve the average FCR in our experiment. This result disagrees with the results of BEERS and Jongbloed 1992a, HopPe et al. 1993 and PALLAUF et al. (1992) but the diets in those experiments were maize-soybean meal-based and young pigs were used. 
Table 5. Bone weights, densities, mineral contents and breaking strength.

\begin{tabular}{|c|c|c|c|c|c|c|c|c|c|c|c|}
\hline Treatment & Diet $1^{1}$ & Diet 2 & Diet 3 & $\mathrm{SEM}^{2}$ & Females & Castrates & SEM & $\mathrm{C}^{3}$ & $\mathrm{C} 2$ & Sex & $\begin{array}{l}\text { Sex* } \\
\text { Diet }\end{array}$ \\
\hline No. of observations & 8 & 8 & 8 & & 12 & 12 & & & & & \\
\hline Tibia weight, g & 191.4 & 192.2 & 192.8 & 6.84 & 188.9 & 195.3 & 5.47 & NS & NS & NS & NS \\
\hline Tibia density, $\mathrm{g} / \mathrm{cm}^{3}$ & 1.224 & 1.145 & 1.216 & 0.0105 & 1.199 & 1.191 & 0.0084 & $* *$ & *** & NS & NS \\
\hline Fibula weight, g & 21.80 & 21.37 & 22.35 & 0.525 & 20.87 & 22.80 & 0.336 & NS & NS & NS & $*$ \\
\hline $\begin{array}{l}\text { Fibula density, } \mathrm{g} / \mathrm{cm}^{3} \\
\text { Ash, } \% \text { of bone }\end{array}$ & 1.321 & 1.289 & 1.257 & 0.0315 & 1.314 & 1.264 & 0.0252 & NS & NS & NS & NS \\
\hline DM (fibula) & 62.12 & 62.88 & 62.02 & 0.588 & 62.49 & 62.19 & 0.447 & NS & NS & NS & $*$ \\
\hline $\begin{array}{l}\text { Calcium, g/kg } \\
\text { ash (fibula) } \\
\text { Phosphorus, g/kg }\end{array}$ & 355.6 & 359.2 & 359.4 & 1.29 & 359.2 & 357.0 & 1.03 & o & NS & NS & NS \\
\hline $\begin{array}{l}\text { ash (fibula) } \\
\text { Breaking strength, }\end{array}$ & 170.6 & 169.0 & 169.0 & 0.74 & 169.6 & 169.4 & 0.59 & NS & NS & NS & o \\
\hline
\end{tabular}

1. Diet $1=$ inorganic $P$ supplementation, Diet $2=$ no inorganic $P$ supplementation, Diet $3=$ like diet $2+$ phytase addition.

2. $\mathrm{SEM}=$ standard error of mean.

3. $\mathrm{C} 1=$ Diet 1 vs. Diets 2 and 3.

$\mathrm{C} 2=$ Diet 2 vs. Diet 3 .

NS non-significant, ${ }^{*}(\mathrm{p}<0.05),{ }^{* *}(\mathrm{p}<0.01),{ }^{* * *}(\mathrm{p}<0.001), \mathrm{o}(\mathrm{p}<0.1)$.

The ADG, as well as the FCR, were most responsive to low dietary $\mathrm{P}$ and to phytase supplementation during the first 45 days (Table 4). During the first two phases group 2 without inorganic P supplement grew 100-120 g less per day than the control pigs and used significantly more feed per $\mathrm{kg}$ weight gain, but after 46 days there was no significant difference in the growth rate of the pigs. This may imply a lower $\mathrm{P}$ requirement in tissue metabolism in older swine, a greater susceptibility of younger animals to high $\mathrm{Ca}$ to $\mathrm{P}$ ratios and/or improved utilization of phytate $\mathrm{P}$ as the animal matures (REINHART and MAHAN 1986). KESSLER and EGLI (1992) found equivalent ADG and FCR's in fattening pigs $(24-107 \mathrm{~kg}$ ) when comparing a phytase-supplemented, low-P wheatbarley-maize-wheat bran diet to a control diet with a normal P level. Cromwell et al. (1991) have reported improved ADG and FCR in fattening pigs on low $\mathrm{P}$ maize-soybean meal diets by the addition of phytase.

There were no differences in carcass weights between the treatments (Table 3). No effect on carcass quality was observed due to the treat- ments, but a sex*diet interaction could be found in carcass quality. This interaction was mainly due to the control group, because in that group the difference was most remarkable between the sexes: all gilts belonged to the best class ( 9 points) while castrates got only 8 points on average. In the other groups the differences were clearly smaller and not significant: 8.6 vs. 8.4 and 8.7 vs. 8.3 for gilts and castrates on diets 2 and 3 , respectively. The castrates on the control diet had the highest ADG and live weight at slaughter, which together probably caused this interaction.

\section{Bones}

No signs of leg weakness were observed in growing pigs receiving lower supplies of $\mathrm{P}$ in their diets. Neither were there any differences in the weights of tibia and fibula bones due to the treatments (Table 5). However, the density of the tibia bone was significantly reduced on low-P diets $(\mathrm{p}<0.01)$. Phytase supplementation to the low $\mathrm{P}$ diet was found to clearly improve the density of the tibia bone $(\mathrm{p}<0.001)$. No significant 
differences were found in the ash or P contents of the fibula bone diaphyses among the experimental diets. The $\mathrm{Ca}$ content in the fibula bone tended to be lower on the control diet. In the balance experiment conducted simultaneously using the same feeds, Ca retention tended to decrease on a P-supplemented compared to unsupplemented diet, but the differences were not significant (NÄSI and HelandER 1994).

The breaking strength of the tibia bones of the control pigs was significantly better $(p<0.01)$ than for pigs on diets without inorganic $\mathrm{P}$ supplementation. Phytase supplementation appeared to improve the breaking strength, but the difference was not significant. Cromwell et al. (1991) reported depressed bone (metacarpals and metatarsals) strength in growing-finishing pigs on cornsoybean meal diets when dietary $\mathrm{P}$ was reduced. The depressions were less pronounced when phytase was included. Bone bending moments decline as the $\mathrm{Ca}$ to $\mathrm{P}$ ratios of the diets widen (REINHART and MAHAN 1986). According to Cromwell (1989), bone breaking strength is more sensitive to dietary P than bone ash. PEO (1991) concluded that in estimating the biological value of $\mathrm{P}$ supplementation, percent bone ash has a high sensitivity for the young, growing animal and a low sensitivity for adults, percent composition of bone ash has a very low sensitivity while physical traits of bone have a high sensitivity. These conclusions concerning adults are confirmed by present results.

The $\mathrm{Ca}$ to $\mathrm{P}$ ratios of the fibula bones were 2.08 to $1,2.13$ to 1 and 2.13 to 1 on diets 1,2 and 3 , respectively. These ratios as well as the $\mathrm{Ca}$ and $\mathrm{P}$ contents of the bones agree with the values reported by PEO (1991). It is interesting that a clear sex effect on bone breaking strength was observed: females had higher tibia bone breaking strength than castrates $(\mathrm{p}<0.05)$. Gilts tended to have more ash, $\mathrm{Ca}$ and $\mathrm{P}$ in the ulna bone than barrows in a trial conducted by CROMWELL et al. (1970), but the differences were not significant. A sex*diet interaction was found in fibula weights and ash content $(\mathrm{p}<0.05)$ and a tendency also in $P$ content $(p<0.1)$ : the bone characteristics of castrates seemed to react to lower $\mathrm{P}$ contents of the diets and to phytase addition more strongly than gilts, perhaps due to their better daily weight gain.

\section{Phosphorus balance}

Knowing the average $\mathrm{P}$ content of the diets, the feed consumption, growth rates and $\mathrm{P}$ retentions (NÄsI and Helander 1994), it was possible to calculate the P balances for every treatment for the whole growth period: $\mathrm{P}$ excretions were $985 \mathrm{~g}, 551 \mathrm{~g}$ and $424 \mathrm{~g} /$ pig on diets 1, 2, and 3, respectively. Therefore, on the low-P diet 2, P excretion was $44 \%$ and on the phytase-supplemented diet 3, 57\% lower than on the control diet.

In conclusion, the results of this study indicate that pigs on barley-soybean meal diets with no inorganic P supplementation, do not perform as well as on diets with a normal P level. The Aspergillus niger phytase preparation improved the performance of the pigs, especially during the grower phases $(28-60 \mathrm{~kg}$ ), but the finishing pigs seemed to grow well without any additional phytase, probably due to the lowered $\mathrm{P}$ requirement or improved phytate P digestibility. No signs of leg weakness could be seen in the live pigs, but the digestible P content of the diets was reflected particularly well in the physical analysis of the bones. These studies should be continued by investigating diets supplemented by a phytase preparation and a small amount of inorganic P during the grower phase, but without any added phytase or inorganic $\mathrm{P}$ during the finisher phase $(60-100 \mathrm{~kg})$. In this way it may be possible to keep the normal performance level, while at the same time decreasing the feeding costs and reducing the $\mathrm{P}$ emissions significantly.

Acknowledgements. The author wishes to thank Mr. K. Andersson, who cared for the experimental animals, and Ms. K. Partanen, M. Sci., and Mr. E. Aimonen, M. Sc., for helping in statistical analyses. The author is grateful to Associate prof. Matti Näsi for his valuable comments on the manuscript. The financial support of the Academy of Finland and Suomen Rehu Ltd. are gratefully acknowledged. 


\section{References}

AOAC 1984. Official methods of analysis. Association of Official Analytical Chemists, Inc. Arlington. Virginia. $1141 \mathrm{p}$.

BeErs, S. \& Jongbloed, A.W. 1992a. Effect of supplementary Aspergillus niger phytase in the diets for piglets on their performance and apparent digestibility of phosphorus. Animal Production 55: 425-430.

- \& JONGBLOED, A.W. 1992b. Apparent overall (total tract) digestibility of $\mathrm{P}$ in relation to doses of Aspergillus niger phytase in diets for pigs. Journal of Animal Science 70(suppl. 1), no. 420.

Cromwell, G.L. 1989. Requirements, biological availability of calcium, phosphorus for swine evaluated. Feedstuffs 61: 16-25.

- \& HAYS, V.W. 1992. The biological availability of phosphorus in feedstuffs for pigs. Pig News and Information 13(2): $75 \mathrm{~N}-78 \mathrm{~N}$.

-, Hays, V.W., Chaney, C.H. \& Overfield, J.R. 1970. Effects of dietary phosphorus and calcium level on performance, bone mineralization and carcass characteristics of swine. Journal of Animal Science 30: 519 525.

-, HaYs, V.W., Scherer, C.W. \& Overfield, J.R. 1972. fects of dietary calcium and phosphorus on performance and carcass, metacarpal and turbinate characteristics of swine. Journal of Animal Science 34: 746.

-, Stahly, T.S. \& RandolPh, J.H. 1991. Effects of phytase on the utilization of phosphorus in corn-soybean meal diets by growing-finishing pigs. Journal of Animal Science 69 (suppl. 1): 358.

Den Hartog, L.A., Tol, J.J., Van Der, Boer, H. \& VerSTEGEN, M.W.A. 1988. Phosphorus digestibility of some anorganic P-sources in pigs determined by quantitative collection of the faeces and with a marker. In: Buraczewska, L. et al. (eds.). Digestive Physiology in the Pig. p. 328-335.

Eeckhout, W. \& DE PAEPE, M. 1992. Influence d'une phytase microbienne sur la digestibilité apparente du phosphore d'aliments pour porcelets. Rev. de L'Agric. 45: 183-193.

ENGlish, P.R., Fowler, V.R., BAXTer, S. \& SMITH, B. 1988. The Growing and Finishing Pig, Improving Efficiency. 1st ed., Farming Press Books. Ipswich, U.K. $555 \mathrm{p}$.

Hoppe, P.P., Schöner, F.-J., WIESChE, H., SChWARZ, G. \& SAFER, S. 1993. Phosphor-Äquivalenz von Aspergillus-niger-phytase für Ferkel bei Fütterung einer Getreide-Soja-Diät. Journal of Animal Physiology and Animal Nutrition 69: 225-234.

JoNGBLOED, A.W. 1987. Phosphorus in the feeding of pigs. Effect of diet on the absorption and retention of phosphorus by growing pigs. I.V.V.O. Report No.179. Lelystad, The Netherlands. 343 p.

-, Everts, H. \& Kemme, P.A. 1991b. Phosphorus availability and requirements in pigs. In: Haresign, W. \& Cole, D.J.A. (eds.). Recent Advances in Animal Nutri- tion. Butterworths. London. p. 65-80.

- \& Kemme, P.A. 1990. Apparent digestible phosphorus in the feeding of pigs in relation to availability, requirement and environment. 1. Digestible phosphorus in feedstuffs from plant and animal origin. Netherlands Journal of Agricultural Science 38: 567-575.

-, Kemme, P.A. \& Mroz, Z. 1991a. Effect of supplementary microbial phytase in diets for pigs on digestibility of $\mathrm{P}$ and phytic acid in different sections of the alimentary tract. Journal of Animal Science 69: 385.

- \& LENIS, N.P. 1993. Excretion of nitrogen and some minerals by livestock. In: Verstegen, M.W.A. et al. (eds.). Nitrogen flow in pig production and environmental consequences. EAAP Publication No. 69. Wageningen. p. 22-36.

Kemme, P.A. \& JongBloed, A.W. 1993. Effect of Aspergillus niger phytase and soaking on the apparent digestibility of $\mathrm{P}$ in diets for pigs. Abstract for the annual meeting of American Society of Animal Science. Spokane, WA.

Kessler, J. \& EGLI, K. 1992. Phosphor sparen dank Phytase, Erste Ergebnisse beim Mastschwein. Landwirtschaft Schweitz 5, 1-2: 5-9.

Ketaren, P.P., Batterham, E.S., Dettmann, E.B. \& FarRELL, D.J. 1993. Phosphorus studies in pigs. 3. Effect of phytase supplementation on the digestibility and availability of phosphorus in soya-bean meal for grower pigs. British Journal of Nutrition 70: 289-311.

Косн, M.E. \& MAнAN, D.C. 1985. Biological characteristics for assessing low phosphorus intake in growing swine. Journal of Animal Science 60: 699-708.

-, Mahan, D.C. \& Corley, J.R. 1984. An evaluation of various biological characteristics in assessing low phosphorus intake in weanling swine. Journal of Animal Science 59: 1546-1556.

Lei, X.G., Ku, P.K., Miller, E.R. \& Yokoyama, M.T. 1992. Influence of dietary phytase activity on utilization of phytate phosphorus in a corn-soybean meal diet for weanling pigs. Report of Swine Research 520. Michigan State University. USA. p. 113-117.

NÄSı, M. \& Helander, E. 1994. Effects of microbial phytase supplementation and soaking of barley-soybean meal diet for improving availability of plant phosphorus for growing pigs. Acta Agriculturæ Scandinavica, Section A., Animal Science 43: 79-86.

OKSBJERG, B.L. 1988. Digestibility and utilization of total phosphorus and phytate phosphorus in cereals for growing pigs. In: Buraczewska, L. et al. (eds.). Digestive Physiology in the Pig. Polish Acad. Sci., Jablonna. p. 352-356.

Pallauf, J., Höhler, D., Rimbach, G. \& Neusser, H. 1992. Einfluss einer Zulage an microbieller Phytase zu einer Mais-Soja-Diät auf die scheinbare Absorption von Phosphor und Calcium beim Ferkel. Journal of Animal Physiology and Animal Nutrition 67: 30-40.

PEO, E.R.,Jr. 1991. Calcium, phosphorus and vitamin D in 
swine nutrition. In: Miller, E.R. et al. (eds.). Swine nutrition. 1th ed., Butterworth-Heinemann. Stoneham, MA, USA. p. 165-182.

PlaAmi, S. \& Kumpulainen, J. 1991. Determination of phytic acid in cereals using ICP-AES to determine phosphorus. Journal of the Association of Official Analytical Chemistry 74: 32-36.

PoInTILlart, A. 1988. Phytate phosphorus utilization in growing pigs. In: Buraczewska, L. et al. (eds.). Digestive Physiology in the Pig. Polish Acad. Sci., Jablonna. p. 319-326.

ReinhaRT, G.A. \& MAhan, D.C. 1986. Effect of various calcium:phosphorus ratios at low and high dietary phosphorus for starter, grower and finishing swine. Journal of Animal Science 63: 457-466.

SAlo, M.-L., TuORI, M. \& KIISKInEN, T. 1990. Rehutaulukot ja ruokintanormit. (Finnish Feedtables). University press. Helsinki. p. 64-65.

SAS 1985. SAS User's Guide, Statistics. 5th Ed. SAS Institute INc. Cary, NC, USA. 956 p.
Simons, P.C.M.,Versteegh, H.A.J., Jongbloed, A.W., Kemme, P.A., Slump, P., Bos, K.D., Wolters, M.G.E., Beuteker, R.F. \& Verschoor, G.J. 1990. Improvement of phosphorus availability by microbial phytase in broilers and pigs. British Journal of Nutrition 64: 525-540.

Snedecor, G.W. \& Cochran, W.G. 1989. Statistical methods. 8th ed. Iowa University Press, Ames, Iowa. 504 p.

TAYSSKY, H.H. \& SHORR, E. 1953. A microcolorimetric method for the determination of inorganic phosphorus. Journal of Biological Chemistry 202: 675-685.

Veevoedertabel 1991. Central veevoederbureau, Lelystad, The Netherlands.

WILDE, R.O. de \& Jourquin, J. 1992. Estimation of digestible phosphorus requirements in growing-finishing pigs by carcass analysis. Journal of Animal Physiology and Animal Nutrition 68: 218-225.

Manuscript received April 1994

\title{
SELOSTUS
}

\section{Mikrobifytaasin vaikutus lihasikojen kasvuun, rehunkäyttöön ja luustoon ohra-soijapohjaisella ruokinnalla}

\author{
EiJa Helander
}

Helsingin yliopisto

\begin{abstract}
Kasvatuskokeessa 72 lihasialla tutkittiin, parantaako mikrobiologisesti tuotettu fytaasi kasvifosforin hyväksikäyttöä ja voidaanko sillä mahdollisesti korvata rehuun normaalisti lisättävä epäorgaaninen fosfori. Kokeessa oli kolme ruokintaryhmää, ja siat kasvatettiin 28 kg elopainosta $101 \mathrm{~kg}$ painoon. Ryhmå 1 oli kontrolliryhmä, jonka rehu täytti nykyiset ruokintanormit. Ryhmä 2 sai muuten samaa rehua, mutta rehuun ei lisätty epäorgaanista fosforia. Ryhmä 3 sai rehua, johon ei lisätty epäorgaanista fosforia, mutta lisättiin $0.024 \%$ Aspergillus niger -mikrobikannalla tuotettua fytaasia.

Koko kasvatuskauden tulokset osoittivat ryhmän 1 sikojen kasvun ja rehun hyväksikäytön olleen paremmat
\end{abstract}

kuin ryhmissä 2 ja 3 . Fytaasi kuitenkin paransi sikojen kasvua ja rehuhyötysuhdetta noin 60 kilon elopainoon saakka. Sen jälkeen ryhmien kasvussa ei ollut merkitseviä eroja. Sikojen teuraslaadussa ei ollut eroja. Sioilla ei esiintynyt kasvatuskauden aikana mitään näkyviä jalkavikoja. Sääriluun tiheys ja murtolujuus olivat kuitenkin kontrolliryhmässä muita ryhmiä paremmat. Fytaasilisäys paransi sääriluun tiheyttä ja murtolujuutta.

Vaikka fytaasi paransikin tuotantotuloksia tietyltä osin, ei kokeen perusteella voi suositella epäorgaanisen fosforin täydellistä korvaamista fytaasilla lihasikojen ohraan ja soijaan perustuvassa ruokinnassa. 